\title{
Film Dokumenter "Ngantung Ari-Ari" Antara Nalar dan Naluri Dari Tradisi Bali Kuno
}

\author{
I Dewa Made Satria Sitangga Wijaya ${ }^{1}$, I Made Agus Wirawan ${ }^{2}$, I Gede Partha Sindu ${ }^{3}$ \\ Program Studi Pendidikan Teknik Informatika \\ Jurusan Teknik Informatika \\ Universitas Pendidikan Ganesha \\ Singaraja, Bali \\ Email : dewatagoer@gmail.com¹, imade.aguswirawan@undiksha.ac.id ${ }^{2}$, partha.sindu@ undiksha.ac.id ${ }^{3}$
}

\begin{abstract}
Abstrak - Penelitian ini bertujuan : 1) Untuk mengembangan Film Dokumenter "Ngantung Ari-ari" antara Nalar dan Nalusi dari Tradisi Bali Kuno di desa Bayunggede. 2) Untuk mengetahui respon masyarakat terhadap hasil akhir Film Dokumenter "Ngantung Ari-ari" antara Nalar dan Nalusi dari Tradisi Bali Kuno di Desa Bayunggede

Penelitian ini merupakan penelitian dan pengembangan yang menggunakan metode Cyclic Strategi, yaitu metode yang menggunakan sistem looping atau pengulangan disetiap tahapnya jika terjadi kekurangan yang ditentukan melalui pengujian. Teknik pengumpulan data dilakukan dengan cara observasi, wawancara, studi literature dan dokumentasi. Penelitian ini diimplementasikan menggunakan Adobe Premiere Pro CS6 sebagai aplikasi pengedit video dan Adobe After Effect CS 6 sebagai aplikasi penambahan efek serta animasi pada video serta menggunakan Adobe Audition Pro CS6 sebagai pengedit suara

Pengujian dilakukan melalui beberapa tahap, yaitu uji ahli isi dan media pra produksi, uji ahli isi dan media pasca produksi hingga uji responden penonton untuk mengetahui pencapaian dan kualitas film. Untuk hasil dari uji responden penonton di dapatkan hasil sangat baik yaitu 96\%. Setelah film ini selesai diharapkan pemahaman masyarakat tentang tradisi terhadap ari-ari baik di gantung maupun di kubur semakin mendalam sehingga dapat meningkatkan rasa toleransi antar umat beragama dan memecahkan konflik yang sedang terjadi.
\end{abstract}

Kata Kunci: Film Dokumenter, Cyclic Strategy, Ngantung Ari-ari

Abstract-The purposes of the study were: 1) To develop a documentary film "Ngantung Ari-ari" antara Nalar dan Nalusi dari Tradisi Bali Kuno in Bayunggede village. 2) To find out the response of the people to the final results of the Documentary Film "Ngantung Ari-ari” antara Nalar dan Nalusi dari Tradisi Bali Kuno in Bayunggede Village

This research was a research and development that used the Cyclic Strategy method, which is a method that uses a looping system at each stage if there are deficiency that determined by testing stage. Data collection techniques were carried out by observation, interviews, literature studies and documentation. This research was implemented using Adobe Premiere Pro CS6 as a video editing application and Adobe After Effect CS 6 as an application for adding effects and animations to videos and using Adobe Audition Pro CS6 as a sound editor.

The test was did through several stages, there were the content expert test and media expert test in pre-production, content expert test and media expert test after the production until the audience respondent tests to determine the achievement and quality of the film. For the results of the test the audience respondents get very good results, by the percentage of 96\%. After the film was finished, it was hoped that the people understanding of the tradition, both hanging and buried and tolerance between religious people is rising and solve the ongoing conflict.

Keywords: Documentery Film, Cyclic Strategy, "ngantung ari-ari”

\section{PENDAHULUAN}

Pelaksanaan tradisi masyarakat di Bali menunjukkan dua ciri besar, yakni masyarakat Hindu "Bali Aga" dan masyarakat Hindu Majapahit [1]. Masyarakat Bali memiliki tradisi perlakuan terhadap Ari-Ari (plasenta) dari seorang anak yang baru lahir. Masyarakat Bali Majapahit memiliki tradisi mengubur ari-ari di pekarangan rumahnya [2]. Berbeda dengan tradisi di Desa Bayunggede, penguburan ari-ari itu dilakukan dengan cara digantung di sebuah tempat yang dikhususkan [1][3].

Setiap ritual keagamaan di Bali yang didasari oleh ajaran Agama Hindu selalu memiliki pesan perdamaian, persatuan dan toleransi yang menembus batas-batas ras, negara, etnik [4] Inilah yang menjalin rasa persaudaraan antar umat menjadi erat sehingga membuat rasa toleransi menjadi tinggi. [1][5] 
Berdasarkan berita yang dirilis oleh Kementerian Agama Bali, pada hari ini dua tradisi yang berbeda yaitu antara "Ngantung Ari-ari" dengan mengubur ari-ari di pekarangan rumah terjadi dalam satu ruang lingkup desa yaitu di desa Bayunggede. Semenjak tahun 2007 banyak masyarakat muda asli Bayunggede mempersalahkan hal ini dengan dasar evolusi dan pengikisan tradisi asli Bayunggede oleh tradisi pendatang. Mereka menuntut masyarakat pendatang tersebut untuk mengikuti tradisi yang telah berkembang di Bayunggede. Namun tuntutan ini ditolak hingga berujung konflik.

Berdasarkan pemaparan di atas, permasalahan yang didapat adalah kurangnya edukasi mulai dari makna tradisi ngantung maupun mengubur secara mendalam dari segi naluri yang selanjutnya dikuatkan oleh nalar yang dijalani oleh umat Hindu dan kurangnya rasa toleransi yang tinggi dalam mehadapi perbedaan yang ada. Maka dirasa perlu dan tepat untuk membuat sebuah film dokumenter tentang tradisi "Ngantung Ari-ari" di Desa Bayunggede dan dilengkapi dengan tradisi mengubur ari-ari yang menjadi tradisi unik. Selain itu diharapkan film ini dapat meningkatkan rasa tolerasi yang tinggi antar golongan manusia.

\section{KAJIAN TEORI}

\section{A. Sejarah Desa Bayunggede}

Berdasarkan hasil hasil wawancara dengan Jero Kubayan Mucuk, beliau menceritakan awal mula adanya desa adat Bayunggede sebagai desa Bali Mula atau Bali aga di awali dengan adanya ceritra nenek moyang yang tidak terdokumentasikan, namun diyakini kebenarannya oleh masyarakat. Desa Adat Bayunggede berawal dengan diutusnya 40 orang undagi (tukang) oleh Ida Bhatara Gunung Semeru di Pulau Jawa untuk datang ke Bali Dwipa (pulau Bali). Tujuan mereka datang ke Bali Dwipa adalah untuk membangun puri dan gelung agung untuk putranya yang ada di Gunung Toh Langtkir (Gunung Agung). Dalam perjalanan undagi tersebut didampingi oleh seekor bojog putih (kera putih) yang merupakan putra dari Bhatara/Dewa Bayu yang dalam cerita ramayana disebut dengan nama Hanoman, dengan dibekali tirta kamandalu. Singkat cerita undagi yang diutus oleh Batara Gunung Semeru tiba di Bali Dwipa bagian selatan tepatnya di alas Rambut Siwi di Kabupaten Tabanan dan disana mereka beristirahat sebentar. Setelah itu mereka melanjukkan perjalananya menuju Gunung Toh Langkir kearah timur laut. Sesampainya ditengah-tengah Bali Dwipa tepatnya dialas mebaong (bentuk hutan yang seperti leher manusia) perjalanan undagi terpisah menjadi dua bagian. Bagian yang satu menuju Gunung Toh Langkir lewat alas Pegametan (Desa Bayunggede Saat ini) sebanyak 20 orang sedangkan sisanya lewat alas Tiing Gading. [1]

Kelompok undagi yang lewat alas Pegametan sesampainya di tengah alas Pegametan (Pura Puaji) menemukan sebuah tued (pangkal pohon) besar, kemudian mereka disana beristirahat dan sambil beristirahat tued itu dipahat menyerupai manusia laki-laki. Setelah itu melanjutkan perjalananya menuju Gunung toh Langkir lewat gunung tuluk Biyu (Bukit Abang ). Di bagian lain bojog putih (Kera Putih) yang memdampingi undagi tiba belakangan di alas Mebaong, dan di sana Tirta Kamandalu yang dibawanya tumpah setengah. Tumpahan sekarang menjadi sebuah sumber mata air yang dikenal dengan Yeh Jati. Kemudian bojog putih (Kera Putih) bersama dengan rombongan melanjutkan perjalananya lewat alas Pegametan dan di sana dia menemukan sebuah patung manusia yang berasal dari tued besar. Karena kemiripannya dengan manusia, maka patung tersebut dihidupkan dengan Tirta Kamandalu yang dibawanya dan setelah hidup manusia laki-laki itu diajak ke Gunung Toh Langkir.

Setibanya di Gunung Toh Langkir manusia tersebut dihaturkan kepada Bhatara Gunung Toh Langkir dan sekaligus diceritakan asal muasal dari manusia tersebut dan yang di alami dalam perjalanan menuju Bali Dwipa dari gunung Semeru Jawa. Setelah mendengarkan cerita tersebut dari bojog putih, Ida Bhatara Gunung Toh Langkir menanyakan undagi yang lain pada bojog putih (Kera Putih), karena yang sudah tiba hanya 20 orang dan sekaligus menugaskannya untuk memcarikan pasangan wanita bagi manusia laki-laki tersebut dengan melakukan yoga ditempat yang berbau perempuan serta ngengetut (mencari) undagi yang lain yang belum sampai di gunung Toh Lakir. Dalam perjanan kembali bojok putih tiba di alas Tiing Gading tepatnya di Pura Dapdap Sakti dan di sana ditemukan patung kayu laki-laki dari tued kayu (pangkal pohon) yang berisi surat mohon untuk dihidupkan, kemudian dengan tirta kamandalu yang dibawanya patung itu dihidupkan, setetah hidup diajak ikut dalam perjalananya. Dalam perjalanannya ke arah barat tepatnya di Belalu ia menemukan pohon yang berlobang tiga dan berbau perempuan. Berdasarkan titah yang telah diberikan oleh Bhatara Toh Langkir, maka bojog putih kemudian melakukan tapa semadi di tempat tersebut. Namun dalam peyogaanya tirta kamandalu yang dibawanya tumpah dan tiba-tiba telah ada seorang manusia perempuan disampingnya. Karena tidak menemukan sang undagi bojog putih (Kera Putih) beserta ketiga manusia tersebut kembali ke Gunung Toh Langkir dan sesampainya di sana ia melihat sang undagi sudah tiba, lalu ia menghaturkan ketiga manusia tersebut kepada Bhatara Toh Langkir serta menjelaskan asal muasalnya. Oleh Ida Bhatara Toh Langkir ketiga manusia yang berasal dari tued (pangkal pohon) tersebut dinikahkan yaitu laki-laki yang ditemukan belakangan dinikahkan denga wanita satunya, sedangkan lakilaki yang pertama akan menikah jika ada perempuan yang mengaturkan diri.

Penyatuan kedua keturunan tersebutlah yang membentuk sebuah desa yang sekarang disebut Desa Bayunggede. Nama Bayunggede sendiri di ambil dari asal manusia pertama di desa ini yakni kayu gede (pohon besar), sehingga disebut Bayunggede. Ada pula yang menyebut nama Bayunggede 
diambil dari Bhatara Bayu, karena manusia yang pertama diurip atau dihidupkan oleh putra Bhatara Bayu sehingga manusia itu dianggap mempunyai Bayunggede (tenaga besar) yang kemudian menjadi Bayunggede. Dilain pihak mengenai sejarah desa Bayunggede juga dikatakan bahwa desa adat Bayunggede didirikan pada tahun icaka 1055, yaitu pada masa Kerajaan Lindu Kerana pada masa itu desa Bayunggede dipimpin oleh tiga orang empu yaitu : Empu Jaya Gama, Empu Jaya Indra dan Empu Laka (hasil pencatatan dokumentasi perencanaan lingkungan desa tradisional Bayunggede, 1989 : 13)

\section{B. Film Dokumenter}

Menurut Undang undang Republik Indonesia Nomor 8 Tahun 1992 tentang Perfilman Bab 1 Pasal 1 Film adalah karya cipta seni dan budaya yang dibuat berdasarkan asas sinematografi dengan direkam pada peta seluloid, pita video, piringan video, dan/atau bahan atau hasil penemuan teknologi lainnya dalam segala bentuk, jenis dan ukuran melalui proses kimiawi, proses elektronik, atau proses lainnya, dengan atau tanpa suara, yang dapat dipertunjukkan dan/atau ditayangkan dengan sistem proyeksi mekanik, elektronik, dan/atau penayangan film [7][8]. Sedangkan pengertian dokumenter menurut Kamus Besar Bahasa Indonesia adalah dokumentasi dalam bentuk film mengenai suatu peristiwa bersejarah atau suatu aspek seni budaya yang mempunyai makna khusus agar dapat menjadi alat penerangan dan alat pendidikan. Jadi bisa disimpulkan film dokumenter adalah sebuah karya cipta seni dan budaya yang dibuat berdasarkan asas sinematografi mengenai suatu peristiwa bersejarah atau suatu aspek seni budaya yang dapat dipertunjukan dengan sistem proyeksi mekanik, elektronik, atau penayangan film [7].

Film dokumenter dipopulerkan oleh John Grierson berkebangsaan Inggris untuk menyebut karya Robert Flaherty (AS) yang berjudul Moana [7].

Dalam program dokumenter terkandung unsur nilai dan faktual. Dalam hal ini faktual berarti nyata, ada dan pernah terjadi. Nilai adalah esensial dan bermakna [7]. Dokumenter adalah dokumen dalam hal ini bisa berupa tulisan, catatan, gambar, film, foto, video dari sebuah peristiwa masa lampau yang memiliki makna bagi suatu lingkungan/daerah, sehingga yang dapat mengetahui dokumen ini adalah sebuah dokumenter adalah lingkungan itu sendiri

Film dokumenter tidak menciptakan suatu peristiwa atau kejadian namun merekam peristiwa yang sungguh-sungguh terjadi atau otentik [7].

\section{Karakteristik Film Dokumenter}

Dalam film dokumenter, cerita yang dituturkan bukan cerita fiktif melainkan cerita yang diangkat dari fakta-fakta yang ada. Menurut [9], Ada empat kriteria yang menerangkan bahwa film dokumenter adalah film non-fiksi.
1. Setiap adegan dalam film dokumenter merupakan rekaman kejadian sebenarnya, tanpa interprestasi imajinatif seperti halnya dalam film fiksi. Bila pada film fiksi latar belakang (setting)adegan dirancang sedemikian rupa sesuai dengan keinginan waktu, tempat dalam adegan, sedangkan pada film dokumenter latar belakang harus spontan dan otentik dengan situasi dan kondisi asli (apa adanya).

2. Yang dituturkan dalam film dokumenter berdasarkan peristiwa nyata (realita), sedangkan dalam film fiksi isi cerita berdasarkan karangan (Imajinatif). Pada film dokumenter memiliki interpretasi kreatif, maka dalam film fiksi yang dimiliki adalah interpretasi imajinatif.

3. Sebagi sebuah film non fiksi, sutradara dalam pelaksanaan produksi film dokumenter melakukan observasi pada suatu peristwa nyata, lalu melakukan perekaman gambar sesuai dengan apa adanya.

4. Apabila struktur cerita pada film fiksi mengacu pada alur cerita atau plot, maka dalam film dokumeter konsentrasinya lebih pada kebenaran isi dan kreatifitas pemaparan dari isi tersebut.

Dalam konsepnya, film ini adalah drama ide yang dianggap dapat menimbulkan perubahan sosial. Karena bukan untuk kesenangan estetis, hiburan atau pendidikan. Tujuannya adalah untuk menyadarkan penonton akan berbagai aspek kenyataan hidup [7][10]. Dengan kata lain, membangkitkan perasaan masyarakat atas suatu masalah, untuk memberikan ilham dalam bertindak, atau membina standar perilaku yang berbudaya. Dalam temanya berkaitan dengan apa yang terjadi atas diri manusia, berupa pernyataan yang membangkitkan keharuan dan kenyataan dalam kerangka kehidupan manusia [11]

\section{Jenis-jenis Film Dokumenter}

Menurut [11] terdapat 6 jenis film dokumenter. Pertama yaitu dokumenter laporan perjalanan, dokumenter sejarah, dokumenter biografi, dokumenter nostalgia, dokumenter investigasi dan dokumenter buku harian

Film dokumenter yang dibuat oleh peneliti termasuk kedalam jenis film dokumenter sejarah dan sedikit masuk ke film dokumenter investigasi karena dalam film ini menceritakan sejarah dari tradisi "Ngantung Ari-ari" dan mengungkap fakta-fakta yang terdapat pada tradisi menggantung maupun mengubur ari-ari tersebut yang diceritakan oleh beberapa narasumber.

\section{E. Tahapan Film Dokumenter}

Menurut [12][13], pembuatan film dokumenter dibagi menjadi tiga tahapan, antara lain pra produksi yaitu pembuatan rancangan seperti ide cerita, sinopsis, skenario dan storyboard. Produksi yaitu pengambilan gambar sesuai dengan rancangan yang dibuat dan pasca produksi yang meliputi proses editing film baik video maupun audio film. Masing-masing tahapan di atas disebut alir proses produksi produk multimedia yang melibatkan banyak runut kerja di dalamnya. 


\section{METODOLOGI PENELITIAN}

Model penelitian yang digunakan untuk film dokumenter Tradisi "Ngantung Ari-ari" adalah model cyclic strategy. Model cyclic strategy atau startegi berputar merupakan sebuah metode yang ada kalanya suatu tahap perlu diulang kembali sebelum tahap berikutnya dilanjutkan. Pengulangan tahap ini sering disebut dengan loop. Pengulangan tahap ini dimaksudkan untuk menampung umpan balik (feed back) sebelum tahap berikutnya dilanjutkan [14]. Berikut adalah gambar tahap-tahap dalam model cyclic strategy yang diimplementasikan ke dalam metodologi penelitian

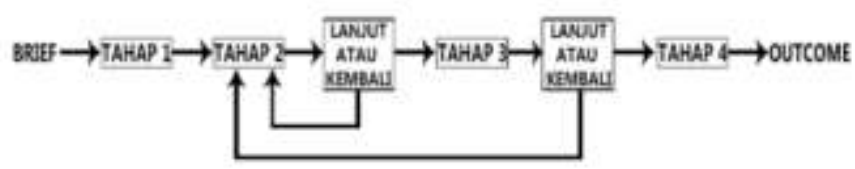

\section{Gambar 1. Bagan Cyclic Strategi}

Berikut penjelasan lebih detail tahap-tahap dalam model cyclic strategy.

\section{A. Brief}

Brief merupakan tahap awal dari perancangan Film Dokumenter "Ngantung Ari-ari" antara Nalar dan Nalusi dari Tradisi Bali Kuno. Pada tahapan ini dibagi menjadi beberapa fase, yaitu :

\section{Pemantapan ide}

Setelah mendapatkan ide/topik film dokumenter, maka akan dimantapkan kembali sebelum ide tersebut akan diajukan dan direalisasikan menjadi sebuah judul film dokumenter.

2. Penawaran ide

Setelah memiliki ide yang cocok untuk dijadikan film dokumenter, maka ide/topik yang tersebut akan diajukan. Namun dalam penelitian ini judul Film Dokumenter "Ngantung Ari-ari" antara Nalar dan Nalusi dari Tradisi Bali Kuno diajukan kepada pihak jurusan untuk mendapatkan persetujuan.

3. Riset awal

Setelah ide/topik diterima, langkah selanjutnya adalah mencari informasi mengenai ide/topik yang telah dirancang.

B. Tahap 1

Pada tahap 1 terdapat beberapa fase, yaitu :

1. Permasalahan

Pada fase ini penulis menemukan permasalahan yang akan dirancang menjadi sebuah film dokumenter. Hasil dari tahap ini dikemas dalam sebuah latar belakang.

2. Pengumpulan data

Pengumpulan data dilakukan setelah permasalahan telah diputuskan. Pengumpulan data yaitu berupa informasi untuk mendukung ide cerita tersebut seperti kejelasan secara detail tradisi, narasumber hingga crew film.

3. Analisis

Data yang sudah terkumpul maka akan dilakukan sebuah analisa guna mengetahui kelebihan, kekurangan, maupun target audiens film dokumenter.

\section{Tahap 2}

Pada tahap 2 terdapat fase pra produksi. Fase pra produksi merupakan tahapan persiapan atau perencanaan dalam pembuatan sebuah film. Tahapan ini berguna untuk mengurangi kesalahan dan meminimalisir kurang koordinasinya komunikasi antar personil yang bertugas agar mampu melaksanakan tugasnya masing-masing. Informasi yang telah terkumpul pada fase pengumpulan data akan dipakai acauan dan bahan dalam fase pra produksi. Pra produksi meliputi beberapa tahapan, yaitu perancangan ide cerita, sinopsis, skenario, dan storyboard.

\section{Evaluasi 1}

Setelah tahap 2 ini akan ada pengujian yang bertujuan untuk memeriksa bahwa semua bagian dalam tahap 1 dan tahap 2 telah terlaksana. Jika ada yang belum terlaksana maka akan dilakukan looping/pengulangan dengan merevisi kembali rancangan film yang terdapat di tahap 1 dan 2. Sedangkan jika semua telah terlaksana maka akan dilajutkan ke tahap berikutnya. Pengujian ini terdiri dari uji ahli isi yang dilakukan oleh 4 orang ahli dan uji ahli media yang dilakukan oleh 2 orang ahli.

\section{E. Tahap 3}

Tahap 3 merupakan tahapan yang penting bagi perancangan film dokumenter ini, karena pada tahap 3 terdapat dua fase penting, yaitu fase produksi dan pasca produksi.

1. Produksi

Fase produksi merupakan tahap pelaksanaan terhadap fase pra produksi. Apabila fase pra produksi telah sesuai dengan ide cerita (konsep), maka fase produksi akan menjalankan yang telah ditetapkan pada fase pra produksi. Pada fase produksi terdapat dua tahapan, yaitu shooting dan recording.

2. Pasca produksi

Fase pasca produksi dapat berjalan setelah proses pada fase produksi telah selesai. Fase pasca produksi merupakan usaha merapikan dan membuat sebuah tayangan film menjadi lebih menarik dan berkualitas. Pada fase ini terdapat tahapan video editing, sound editing, rendering, dan review editing.

\section{F. Evaluasi 2}

Setelah tahap 3 ini akan ada pengujian yang bertujuan untuk mengecek kembali apakah pada tahap 3 telah terlaksana. Jika ada yang belum terlaksana maka akan dilakukan looping / pengulangan dengan merevisi kembali tahap tersebut. Pengujian yang dilakukan akan menggunakan media kuesioner. Pengujian ini terdiri dari uji ahli isi yang dilakukan 
oleh 4 orang ahli dan uji ahli media yang dilakukan oleh 2 orang ahli. Hasil dari kuesioner ini akan menjadi sebuah pertimbangan apakah film dokumenter ini perlu di revisi atau tidak. Bila terjadi revisi maka akan terjadi pengulangan pada fase pasca produksi.

G. Tahap 4

Tahap 4 merupakan tahapan akhir sebelum film ini disebarluaskan. Pada tahap 4 ini terdapat fase mastering. Mastering merupakan proses dimana file yang telah di-render dipindahkan kedalam media kaset, $V C D, D V D$ atau media lainya.

H. Outcome

Outcome merupakan tahapan terakhir dari pembuatan film dokumenter ini. Tahap terakhir yaitu publikasi. Produk akhir film yang telah dikemas dalam bentuk DVD siap dipublikasikan, target publikasi disesuaikan dengan target penonton.

\section{HASIL DAN PEMBAHASAN}

\section{A. Dasar Tradisi Ari-ari}

Berdasarkan ajaran umat Hindu yaitu Kanda Pat yang artinya empat saudara dari seorang manusia yang baru lahir, menyebutkan bahwa salah satu dari 4 saudara manusia adalah ari-ari, sehingga wajib untuk diupacarai dan diperilakukan seperti manusia itu sendiri untuk senantiasa menjaga manusia tersebut dari hal-hal yang negatif. Upacara tersebut baik dilakukan dengan cara dikubur maupun digantung seperti di Desa Bayunggede Bangli.

Berdasarkan sejarah yang diyakini kebenarannya oleh masyarakat Bayunggede bahwa asal mula dari kehidupan manusia yang hidup di Desa Bayunggede berasal dari sebuah tued kayu (pangkal pohon) yang diukir layaknya seorang manusia oleh seorang undagi dan dihidupkan menggunakan tirta kamandalu yang dibawa dari pulau Jawa oleh titisan dari Bhatara Вауи Masyarakat Bayunggede yakin bahwa wujud manusia berawal dari pangkal pohon yang direstui oleh Bhatara Bayu, sehingga saat anak manusia yang lahir harus dikembalikan ke asalnya yaitu kayu. Ari-ari dibungkus menggunakan kelapa dan di gantung di pohon khusus yang namanya pohoh bukak. Pohon ini memiliki buah yang jika sudah matang/tua terbelah menjadi 2 yang melambangkan alat vital seoran perempuan (ibu). Pohon ini diyakini akan menjaga ari-ari layaknya seorang ibu dalam menjaga anaknya.

\section{B. Sarana Tradisi}

Tradisi ngantung ari-ari ini memerlukan sarana yang tidak sedikit. Semua sarana memili makna yang berbeda dan diyakini berpengaruh oleh masyarakat Bayunggede.

1. Tempurung kelapa. Kelapa dipilih sebagai pembungkus ari-ari karena kelapa memiliki tekstur yang sangat kuat dan keras sehingga susah untuk ditembus rayap atau serangga. Kelapa memiliki 3 bagian utama, yaitu air, isi dan tempurung, sehingga diyakini juga bayi akan memiliki memiliki sikap yang halus dan bersih seperti air, memiliki pemikiran dan ilmu yang berguna dan memiliki kekuatan fisik seperti tempurung kelapa

2. Ngad (pisau bambu). Jaman dahulu sebelum adanya pisau atau gunting di tempat persalinan, masyarakat Bayunggede masih menggunakan pisau dari bambu untuk memotong tali pusat yang masih tersambung dengan bayi. Ngad juga dimasukkan kedalam tempurung kelapa, diyakini sebagai sesikep yang nantinya digunakan sebagai alat berperang melawan adharma dan Sad Ripu manusia.

3. Sepit (penjepit bambu). Sepit digunakan untuk mengambil ari-ari untuk dimasukkan kedalam tempurung kelapa dan dimasukkan juga ke dalam tempurung kelapa. Sepit memiliki dua bagian yang digunakan untuk menjepit, diharapkan bayi memiliki sikap yang sama seperti sepit yang melambangkan jiwa solidaritas, jika digunakan menjepit bara api maka kedua bagian akan terkena panas.

4. Tengeh, merupakan racikan yang dibuat dari Kunyit yang dilumatkan dan dicampur dengan kapur sirih. Secara biologis kunyit dan kapur sirih ini dapat digunakan sebagai bahan pengawet yang membuat organ menjadi kering dan untuk menekan bau dari pembusukan di udara. Kunyit memiliki warna yang kuning dan kapur sirih memiliki warna yang putih, diyakini akan membuat bayi memiliki kulit yang putih atau kuning langsat.

5. Anget-anget, terdiri dari ketumbar dan cengkeh. Kedua bahan ini memiliki kasiat dalam menghangatkan tubuh manusia. Hal ini juga diyakini dapat menjaga suhu tubuh bayi agar tetap hangat dan tidak kedinginan karena Desa Bayunggede terletak di daerah pegunungan.

6. Abu dapur, digunakan untuk mengubur ari-ari terakhir yang dapat menekan bau akibat pembusukan dan untuk menyerap cairan yang ditibulkan akibat pembusukan terjadi.

7. Kapur sirih, digunakan untuk merekatkan kembali tempurung kelapa yang sudah terbelah. Kapur sirih/pamor digunakan untuk menutup seluruh rongga yang ada akibat terbelahnya kelapa pemungkus ari-ari. Pamor akan menjadi kering dan padat selama 1 hari.

8. Tali bambu, tali bambu digunakan untuk mengikat tempurung kelapa dan digunakan untuk menggantung ariari tersebut.

\section{Proses Tradisi}

Berdasarkan hasil wawancara bersama Jero Kubayan Mucuk (Sulinggih di Desa Bayunggede) setiap orang yang memiliki bayi pastinya dilahirkan di rumah sakit atau di puskesmas terdekat. Proses persalinan memiliki beberapa proses salah satunya yaitu pemisahan bayi dengan ari-ari dengan memotong tali pusat bayi. Jaman dahulu proses ini masih menggunakan ngad (pisau dari bambu) namun sekarang sudah menggunakan gunting dan selanjutnya ari-ari di bawa ke rumah. Sesampainya di rumah, ari-ari dibersihkan 
menggunakan air untuk menghilangkan kotoran-kotoran seperti darah atau air ketuban. Hal ini bertujuan untuk memelihara ari-ari layaknya manusia yang akan melakukan upacara yadnya, sebaiknya harus dibersihkan secara fisik.

Proses selanjutnya adalah mempersiapkan sarana tradisi. Proses ini wajib dilakukan di dapur. Sarana yang pertama disiapkan adalah kelapa. Kelapa yang dipilih sesuai dengan ukuran ari-ari yang ada, selanjutnya kelapa dibersihkan dari serat-seratnya hingga menjadi "gundul". Membersihkan kelapa ini diyakini bahwa jika ari-ari ditempatkan di tempat yang bersih maka akan muncul pula sikap bersih kepada bayi atau anak yang memiliki ari-ari tersebut. Setelah kelapa bersih, kemudian kelapa dibelah menjadi dua bagian.

Langkah selanjutnya yaitu memasukkan ari-ari kedalam kelapa. Proses ini menggunakan sarana sepit untuk menjepit ari-ari. Sepit adalah penjepit yang dibuat dari bambu. Setelah itu, ari-ari di campurkan mengunakan tengeh hingga berwarna kuning dan ditaburkan anget-anget di atas ar-ari tersebut, selain anget-anget, sarana ngad dan sepit juga dimasukkan ke dalam ari-ari tersebut. kemudian dikubur terakhir menggunakan abu dapur.

Setelah semua proses diatas dilakukan, maka kelapa direkatkan kembali menggunakan pamor (kapur sirih). Pamor dioleskan diseluruh bagian kelapa yang terbelah sebelumnya dan dioleskan juga secara membujur sehingga membentuk tanda tambah seperti gambar 2.

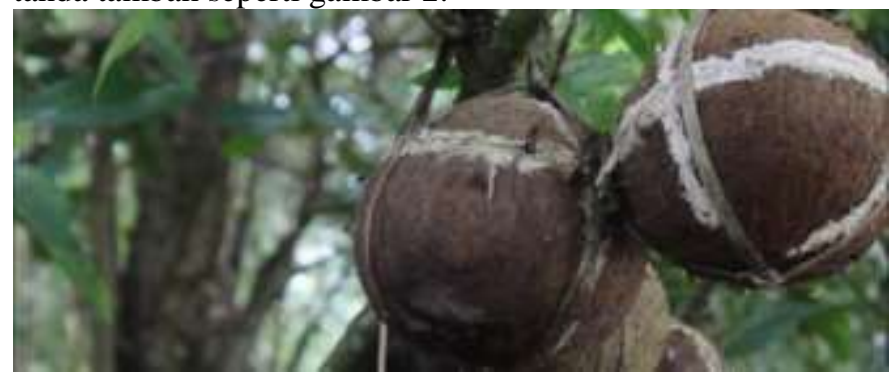

Gambar 2. Pengolesan pamor

Mengoleskan pamor diharapkan dengan rapi, karena diyakini bahwa kerapian pamor ini juga akan berpengaruh dengan sikap rapi dari bayi itu sendiri. Pamor digunakan untuk merekatkandua belah kelapa tersebut. Selama 1 hari pamor akan kering sehingga menutup seluruh rongga yang ada pada kelapa. Tertutupnya rongga ini membuat sulitnya masuk serangga yang dapat mengganggu proses pembusukan dari ariari di dalam kelapa. Setelah direkatkan dengan kapur sirih, kemudian kelapa tersebut diikat menggunakan tali bambu dengan simpul salang tabu. Simpul salang tabu berbentuk segi empat seperti gambar 3 .

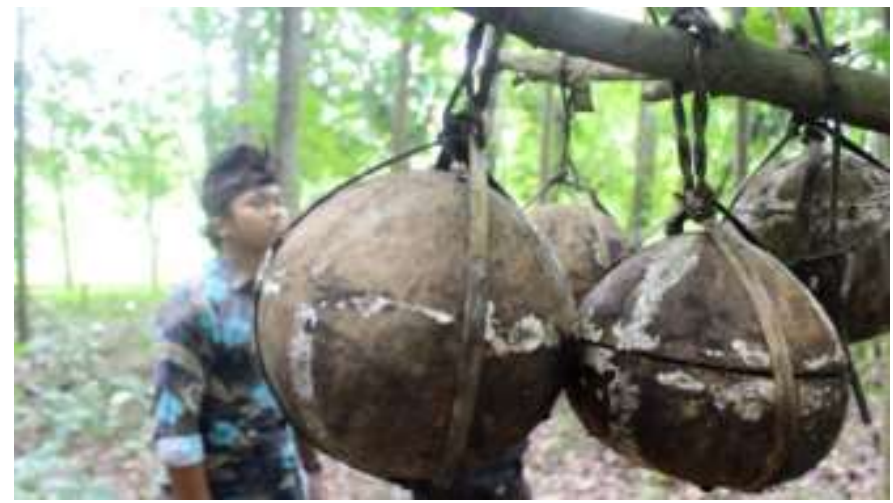

Gambar 3. Simpul Salang Tabu

Mengikat tali dengan simpul salang tabu adalah tahap persiapan terakhir di rumah. Setelah itu dilakukan persiapan untuk proses menggantung. Orang yang menggantung adalah keluarga dari bayi itu sendiri baik ayah, ibu, kakek, nenek namun biasanya adalah sang ayah. Kemudian ayahnya mengganti pakaian dengan rapi layaknya seorang umat yang akan melakukan upacara yadnya. Ari-ari akan digantung di sebuah areal khusus yang disebut dengan "Setra Ari-ari" yang terletak di dekat kuburan desa. Luas dari setra ari-ari ini sekitar 60 are yang dipenuahi oleh pohon bukak dan pohon lainnya layaknya sebuah hutan. Sebelum menuju setra ari-ari sang ayah wajib membawa sabit yang ukurannya besar untuk menjaga diri sebagai hewan buas dan digunakan untuk menebas ranting pohon bukak tempat menggantung ari-ari.

Ari-ari dibawa ke setra ari-ari menggunakan tangan kanan. Perjalanan ini dilarang dilakukan lebih dari satu orang. Sang ayah yang membawa ari-ari dalam perjalanannya harus tetap fokus dan tidak terganggu oleh lingkungan sekitar, hal ini diyakini bahwa akan berpengaruh ke sikap bayi untuk bisa fokus dalam belajar maupun bekerja. Sesampainya di setra ariari, sang ayah mencari tempat untuk menggantung ari-ari.

Filosopi dan keyakinan dalam menggantu ini yaitu jika ariari digantung di pohon yang ramai dengan ari-ari, maka diyakini bayi akan banyak memiliki teman. Jika ari-ari digantung di tempat yang tinggi diyakini akan menjadi pemimpin. Jika digantung di tempat yang sepi maka dipercaya akan menjadi pribadi yang senang berpetualang, memiliki pemikiran dan penapilan yang berbeda.

Setelah sang ayah menentukan tempat menggantungkan ari-ari, maka ari-ari akan ditimpangkan ke tangan kiri, dan tangan kanan mengambil sabit untuk menebas ranting pohon tampat menggantungnya. Kemudian ari-ari digantung dengan tangan kanan karena perilaku menggunakan tangan kana merupakan simbol kesopanan. Hal ini pernah terjadi saat seseorang menggantung ari-ari menggunakan tangan kanan, sang bayi menjadi orang dengan dominan hal yang dilakukan menggunakan tangan kiri atau kidal, selain itu bertujuan untuk menumbuhkan sikap sopan terhadap bayi. 
Setelah proses ini, sang ayah wajib mencari tanaman paku dan kayu bakat untuk dibawa pulang. Sampai dirumah, paku diikat di gerbang rumah. Hal ini bertujuan sebaga petanda bahwa di dalam rumah tersebut sedang ada bayi yang baru lahir. Keberadaan bayi ini akan membuat orang yang berkunjung ke rumah itu menjadi cuntaka sehingga tidak dapat ke tempat suci selama hari itu. Kayu bakar akan digunakan untuk menyalakan api di dapur sebagai lambang penghangat untuk bayi.

Selama 12 hari, sang ayah wajib mesimbuh, yaitu menyemburkan bawang putih dan jangu yang dikunyah sebelumnya. Hal ini bertujuan untuk menjaga bayi dari gangguan makhluk halus karena dipercaya bahwa bawang putih dan jangu ditakuti oleh hal-hal yang bersifat negatif.

\section{Film Dokumenter "Ngantung Ari-ari"}

Pembuatan Film Dokumenter "Ngantung Ari-ari" Antara Nalar dan Naluri dari Tradisi Bali Kuno menerapkan model cyclic strategy. Model cyclic strategy memilki delapan bagian yaitu brief, tahap 1 , tahap 2 , evaluasi 1 , tahap 3 , evaluasi 2 , tahap 4 dan outcome. Tahap brief yaitu menganalisis permasalahan yang ada (pemantapan ide), pengajuan ide kepada pihak program studi Pendidikan Teknik Informatika, dan melakukan riset awal dari beberapa literatur yang ada. Setelah itu akan dilanjutkan ke tahap 1 yaitu melakukan pengumpulan data dan analisis kebutuhan.

Tahap pengumpulan data, dilakukan pencarian informasi kepada masyarakat serta narasumber tentang tradisi menggantung maupun mengubur ari-ari serta konflik yang terjadi di Desa Bayunggede. Setelah semua informasi terkumpul. Kemudian pada tahap analisis, dilakukan analisis talent, analisis lokasi, analisis alat, analisis crew, analisi SWOT dan analisis STP

Tahap 2 dilakukan tahapan pra produksi film yaitu pembuatan ide cerita, sinopsis, skenario, dan storyboard yang akan dijadikan acuan saat pengambilan gambar pada tahap produksi. Berikut adalah hasil tahap pra produksi

a) Ide Cerita

Menekankan pada tujuan utama film dokumenter ini adalah untuk menyampaikan informasi tentang makna yang terkandung dalam tradisi menggantung atau menanam ari-ari baik secara Sekala dan Niskala. Informasi yang disampaikan melalui tokoh - tokoh yang tentu memahami tentang tradisi tersebut yang selanjutnya disebut dengan narasumber. Film dokumenter yang dibuat dimulai dari konflik yang terjadi di desa tersebut. Film ini diperankan oleh seorang pemuda tersebut yang ingin meningkatkan rasa toleransi antara kedua belah pihak dengan mengungkap makna-makna yang terkandung di dalam tradisi tersebut.

b) Sinopsis
Sebuah konflik yang disababkan oleh 2 tradisi yang berbeda telah mencuat di beberapa media, yaitu tradisi tentang "ngantung ari-ari" dan telah dibaca oleh seorang pemuda yang gemar berkecimpung dengan tradisi. Dewa, itulah sebutan namanya. Ia merasa terpanggil untuk menelusuri makna-makna dan letak kesalahan tradisi tersebut sehingga membuat konflik dingin di sebuah desa di Kintamani yaitu Desa Bayunggede. Hanya bermodalkan niat dan rasa penasaran serta informasi dari media, Dewa berjalan dari titik ke titik untuk menemukan narasumber yang bisa memberikan informasi terkait dengan tradisi yang dipermasalahkan. Informasi tersebut dikemas dalam sebuah tulisan dan ia yakin kelak nanti informasi ini akan dapat memperkuat keyakinan masyarakat terhadap tradisi dan rasa toleransi akan perbedaan tradisi yang ada. Dewa akan menuntun dan mengungkap seluruh makna dari tradisi ngantung dan menanam ari-ari yang sudah sering kita lakukan

c) Skenario

Sekenario dari film ini adalah naskah yang berisikan tentang percakapan, lokasi, waktu dan suasana dari film ini. Untuk mempermudah dalam pengambilan gambar dan proses editing dibuatlah benang merah dari cerita ini yang selanjutnya disebut dengan story line yaitu i) Pembuakaan akan diisi dengan video teaser tentang Film ini yaitu ditampilkannya beberapa cuplikan film yang dapat membuat penonton penasaran terhadap film ini dan dilanjutkan dengan judul dari Film ini. ii) Babak 1, akan menampilkan dan memperkenalkan pemeran utama yaitu Dewa yang sedang membaca berita tentang tradisi agama Hindu. iii) Babak 2, Dewa mencari informasi tentang konflik yang melanda tradisi ini di badan Kesbangpol Linmas kabupaten Bangli. iv) Babak 3 menjelaskan tentang tahap-tahap serta makna dari tradisi ngantung ariari dan dilengkapi dengan penjelasan singkat terkait dengan konflik yang terjadi. v) Babak 4 menjelaskan tentang tahap-tahap dan makna dari mengubur ari-ari di pekarangan rumah, serta meminta saran untuk konflik yang terjadi. vi) Babak 5 menceritakan bahwa secara medis juga terdapat keterkaitan antara plasenta (ari-ari) bayi dengan bayi tersebut pasca kelahiran. vii) Penutup dari film ini adalah Dewa menyimpulkan perjalanan yang dilakukan

Tahap selanjutnya yaitu evaluasi 1 untuk mengevaluasi tahap 1 dan tahap 2. Pada tahap ini dilakukan uji ahli isi, dan uji ahli media. Uji ahli isi dilakukan dengan instrumen angket dan melibatkan empat orang ahli, diperoleh hasil rata-rata persentase penilaian yang didapat yaitu sebesar $100 \%$ sehingga dapat dikatakan kelayakan isi yang akan ditampilkan sudah sesuai dengan data dan fakta yang sebenarnya. Sedangkan uji ahli media menggunakan instrumen angket dan melibatkan dua orang ahli yang berkompeten dalam bidang 
film dokumenter. Setelah dilakukan pengujian diperoleh hasil rata-rata persentase penilaian yaitu sebesar $100 \%$, sehingga dapat dikatakan layak untuk dilanjutkan ke tahap produksi.

Setelah evaluasi 1 selesai, dilanjutkan ke tahap 3 yaitu tahapan produksi dan pasca produksi Film Dokumenter "Ngantung Ari-ari" Antara Nalar dan Naluri dari Tradisi Bali Kuno. Pada tahapan produksi dilakukan proses pengambilan gambar (shooting) di lokasi-lokasi yang telah ditentukan dan pembuatan ilustrasi dengan reka adegan. Berikut adalah hasil dokumentasi dari tahap produksi

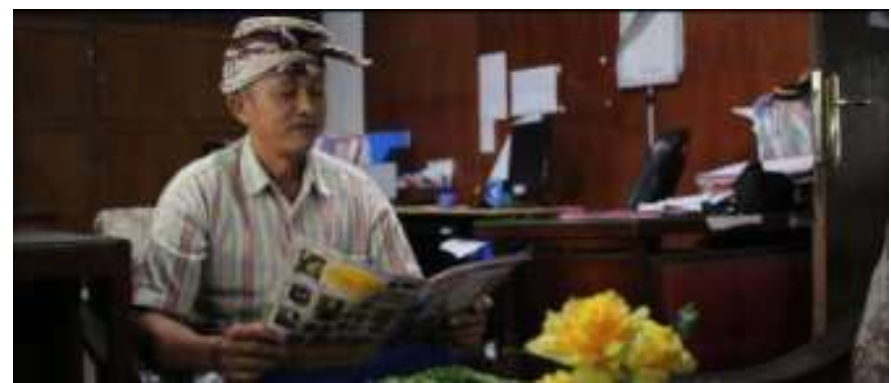

Gambar 4. Pengambilan Gambar Babak1

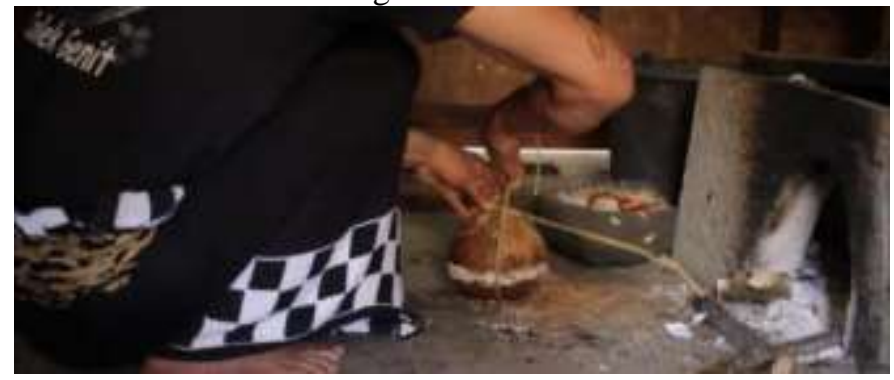

Gambar 5. Pengambilan Gambar Babak2

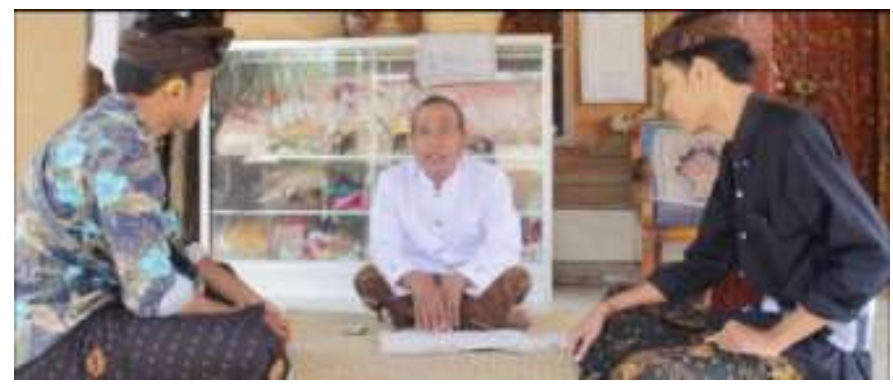

Gambar 6. Pengambilan Gambar Babak 3

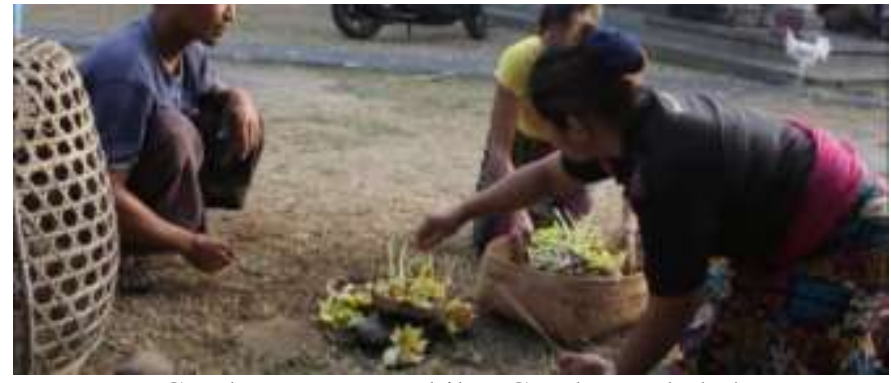

Gambar 7. Pengambilan Gambar Babak 4

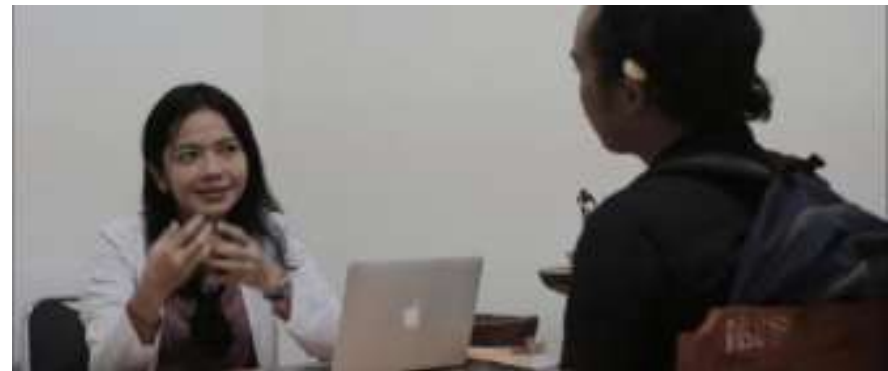

Gambar 8. Pengambilan Gambar Babak 5

Setelah proses pengambilan gambar selesai kemudian dilakukan tahapan pasca produksi yang terdiri dari proses editing dan rendering.

Setelah tahap 3 selesai, maka dilanjutkan evaluasi 2. Uji ahli isi dilakukan dengan instrumen angket dan melibatkan 4 ahli, diperoleh hasil rata-rata persentase penilaian yaitu sebesar $100 \%$, sehingga sudah sesuai dengan rancangan yang dibuat dan fakta yang sebenarnya. Sedangkan untuk uji ahli media dilakukan dengan instrumen angket dan melibatkan 2 ahli dalam bidang film dokumenter, diperoleh hasil rata-rata persentase penilaian yaitu sebesar $85 \%$, sehingga dapat dikatakan memenuhi penilaian dari ahli media dan dapat dipublikasikan.

Pada tahap 4 dilakukan proses burning file yang sudah dirender, kemudian dikemas dalam bentuk DVD dan dapat dipublikasikan. Dilanjutkan ke tahap outcome yaitu mempublikasian Film Dokumenter "Ngantung Ari-ari" Antara Nalar dan Naluri dari Tradisi Bali Kuno dalam bentuk DVD yang telah dibuat dan disosialisasikan dengan media poster. Berikut adalah hasil dari tahap 4 


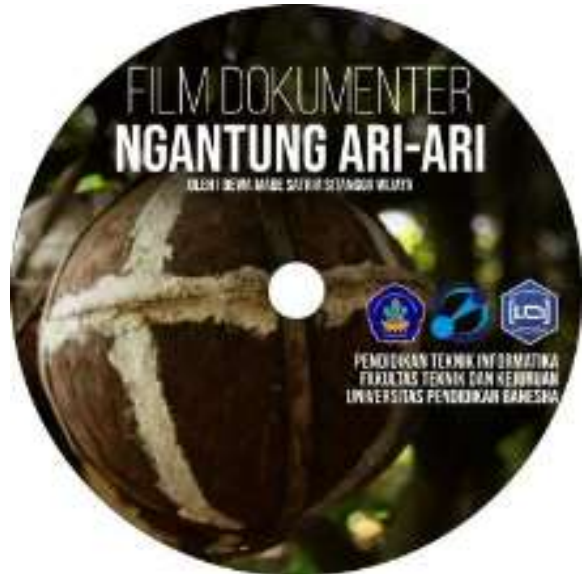

Gambar 9. Desain Kepingan DVD

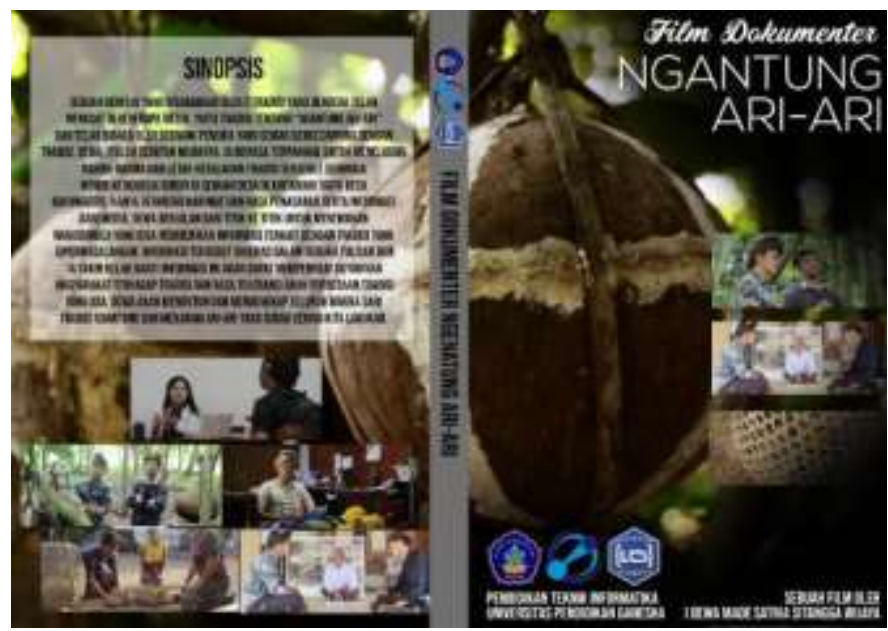

Gambar 10. Desain Cover DVD

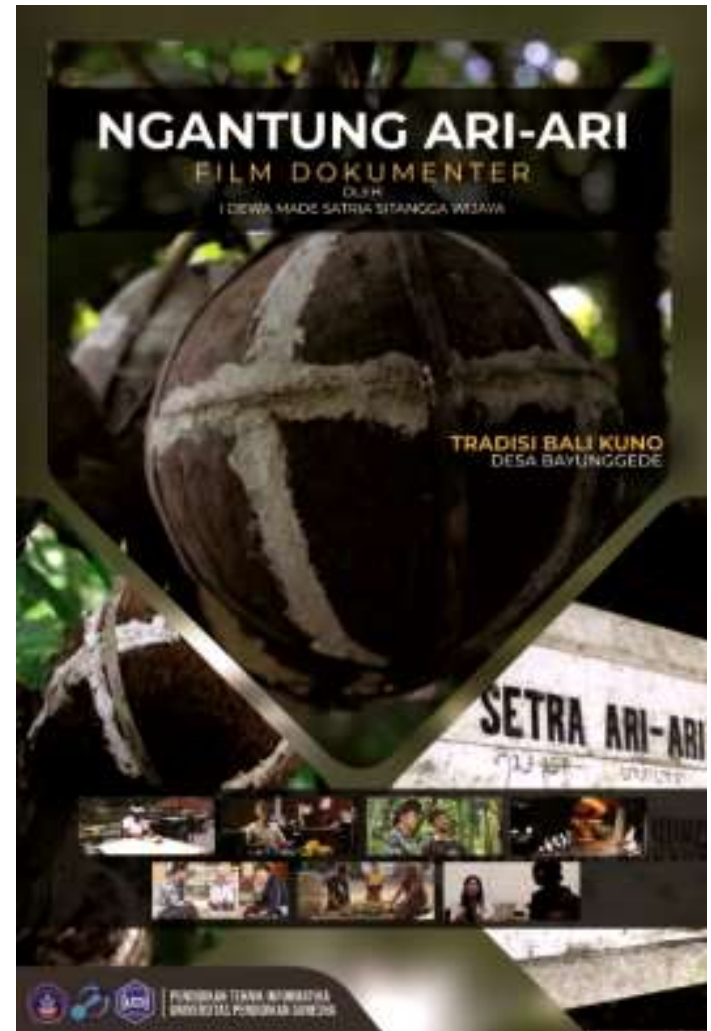

Gambar 11. Desain Poster

Setelah semua tahap dilalui, maka akan dilakukan uji respon penonton untuk mengetahui respon dari penonton setelah menonton film. Pengujian ini menggunakan angket skala lima dengan melibatkan 30 responden yang dipilih secara acak, diperoleh hasil rata-rata persentase penilaian yang didapat yaitu sebesar 96\% masuk dalam kategori Sangat Baik.

Film dokumenter ini dapat menyampaikan realita yang ada di lapangan dengan inovasi yang lebih menarik untuk mengetahui informasi tentang makna tradisi menggantung maupun mengubur ari-ari secara keyakinan dan secara ilmiah. Film Dokumenter "Ngantung Ari-ari" Antara Nalar dan Naluri dari Tradisi Bali Kuno dibuat dengan tujuan untuk memperkenalkan dan memberikan wawasan tentang makna tradisi menggantung maupun mengubur ari-ari secara keyakinan dan secara ilmiah bagi penonton serta toleransi antar umat yang memiliki keyakinan yang berbeda. Sehingga, masyarakat yang sebelumnya kurang mengetahui tentang tradisi ini, setelah menonton film ini setidaknya menjadi lebih tau dan yakin dengan tradisi terhadap ari-ari bayi yang baru lahir memiliki keterkaitan yang sangat erat dengan bayi itu sendiri. 


\section{SIMPULAN}

\section{A. Simpulan}

Berdasarkan hasil penelitian dan pembahasan Film Dokumenter "Ngantung Ari-ari” Antara Nalar dan Naluri dari Tradisi Bali Kuno, maka penulis dapat menarik kesimpulan sebagai berikut:

Implementasi Film Dokumenter "Ngantung Ari-ari" Antara Nalar dan Naluri dari Tradisi Bali Kuno telah berasil dilaksanakan dengan menggunakan motode cyclic strategy dan menggunakan tahapan produksi film yaitu pra produksi, produksi dan pasca produksi. Film Dokumenter "Ngantung Ari-ari" Antara Nalar dan Naluri dari Tradisi Bali Kuno merupakan sebuah media publikasi yang dapat digunakan untuk memberikan edukasi kepada masyarakat tentang maknamakna dari tradisi terhadap ari-ari yang sering dilakukan oleh umat hindu dan untuk meningkatkan rasa toleransi antar umat beragama terhadap hal yang bersifat baru. Sebelum dipublikasikan film ini sudah diujikan kepada empat orang ahli isi dan dua orang ahli media menggunakan intsrumen angket. Berdasarkan uji ahli isi diperoleh persentase sebesar $100 \%$. Sedangkan berdasarkan uji ahli media diperoleh persentase yang sama yaitu sebesar $85 \%$.

Berdasarkan hasil uji respon penonton Film Dokumenter "Ngantung Ari-ari" Antara Nalar dan Naluri dari Tradisi Bali Kuno yang melibatkan 30 responden diambil secara acak memperoleh persentase sebesar $96 \%$. Hasil yang diperoleh ini dikategorikan ke dalam pencapaian sangat baik. Jadi informasi yang terdapat pada Film Dokumenter "Ngantung Ari-ari" Antara Nalar dan Naluri dari Tradisi Bali Kuno telah tersampaikan dengan sangat baik

\section{B. Saran}

Apapun yang dilakukan terkait dengan penelitian, baik observasi maupun wawancara bersama narasumber, disarankan untuk melakukan shooting, karena momen dari film dokumenter biasanya muncul secara tidak disengaja pada seluruh tahapan.

Memilih pemeran utama yang memang memiliki pengalaman sebagai aktor dan tentunya bisa ber-acting dan menguasai materi film, sehingga dapat membantu proses produksi dan memberikan efek yang nyata dalam film.

Berani untuk mencari, menggali dan mempublikasikan fakta-fakta terkait dengan objek film dokumenter yang selama itu disembunyikan.

Menyiapkan media penyimpanan (memory card) minimal 32 Gb type Extreme, untuk menghindari error stop recording pada kamera saat momen berlangsung.

Mengambil gambar minimal dari 2 sudut kamera yang berbeda saat wawancara maupun momen berlangsung untuk mempermudah proses editing.
Proses recording saat wawancara sebaiknya menggunakan recorder yang posisinya dapat disembunyikan dan dekat dengan sumber suara. Jika recorder berupa handphone, tidak disarankan menaruh handphone di dalam saku baju.

\section{REFERENSI}

[1] Arta, K. S. (2011). Prosesi Upacara Ari-Ari dengan Sistem Gantung. Jurusan Pendidikan Sejarah, UNDIKSHA, 2-15.

[2] Lisiana, N. L. (2014). PEMERTAHANAN TRADISI PENGUBURAN ARI-ARI PADA MASYARAKAT BALI AGA DI DESA PEKRAMAN BAYUNG GEDE, KINTAMANI, BANGLI. Jurusan Pendidikan Sejarah, UNDIKSHA, 14.

[3] Pangasih, F., \& Asvitasari, A. (2016). PERGESERAN KONSEP MORFOLOGI PADA DESA BALI AGA Studi Kasus: Desa Bayung Gede dan Desa Panglipuran. Program Pascasarjana, Magister Teknik Arsitektur, Universitas Atmajaya Yogyakarta, 1-15.

[4] Suacana, W. G. (2011). Budaya Demokrasi dalam Kehidupan Masyarakat Desa di Bali . JURNAL KAJIAN BALI Volume 01, Nomor 01, 1-5.

[5] Nonoriati, N. W., Sendratari, L. P., \& Arta, K. S. (2014). TRADISI NGREKES DI DESA PAKRAMAN MUNTIGUNUNG, KUBU, KARANGASEM BALI. Jurusan Pendidikan Sejarah, UNDIKSHA, 2-14.

[6] Dr. Ir. Nurrahman., M. (2014). Anti Mikroba dari Rempah Rempah dan Herbal. TPC Project Udayana University - Texas A\&M University, 53-65.

[7] Sumarno, M. (2010). Dasar-Dasar Apresisasi Film. Jakarta: Grasindo.

[8] Effendy, H. (2008). Industri Perfilman Indonesia Sebuah Kajian. Jakarta: Erlangga.

[9] Rikarno, R. (2015). Film Sebagai Sumber Belajar Siswa Ekspresi Seni. Ekspresi Seni, 29.

[10] Eko, A. M. (2013). Simulasi Digital. Jakarta: Kementerian Pendidikan dan Kebudayaan.

[11] Putra, I. D., Darmawiguna, I. G., \& Pradnyana, G. A. (2017). Film Dokumenter Anjing Bali Tuan Rumah, Sejuta Kisah. Kumpulan Artikel Mahasiswa Pendidikan Teknik Informatika (KARMAPATI) Volume 6, Nomor 1, 1-8.

[12] Fachruddin, A. (2012). Dasar-Dasar Produksi Televisi. Jakarta: PT Fajar Interpratama Mandiri. 
[13] Ayawaila, G. R. (2008). Dokumenter Dari Ide Sampai Produksi. Jakarta: Lembaga Pendidikan Fakultas Film dan Televisi - Institut Kesenian Jakarta.

[14] Sarwono, J., \& Lubis, H. (2007). Metode Riset untuk Desain Komunikasi Visual. Yogyakarta: Andi Publisher 